\title{
PENGARUH POTONGAN HARGA, PROMOSI PENJUALAN, TAMPILAN DALAM TOKO TERHADAP KEPUTUSAN PEMBELIAN IMPULSIF KONSUMEN MATAHARI DEPARTEMENT STORE PADANG
}

\author{
Ahmad Salim, Riche Fermayani \\ STIE Perbankan Indonesia \\ ahmadsalim@,gmail.com, richefermayani@gmail.com
}

\begin{abstract}
Absctract: This study aims to determine the effect of Price Discounts, Sales Promotions, Store Appearances on Impulsive Purchasing Decisions Consumers of Matahari Department Store Padang. The samples studied in this study were 100 respondents who were consumers of Matahari Department Store Padang. Based on the statistical t test carried out, it can be concluded that the variable discounted price has a positive and significant effect on impulsive purchasing decisions indicated by a significance value of $0.047<$ alpha 0.05 . Based on the statistical t test conducted, it can be concluded that sales promotion has a positive and significant effect on impulsive purchasing decisions indicated by a significance value of 0,000 $<$ alpha 0.05. Based on the statistical t test performed, it can be concluded that the appearance in the store has a positive and significant effect on impulsive purchasing decisions indicated by a significance value of $0,000<$ alpha 0.05. Based on the simultaneous $f$ test obtained a significance value of $0,000<0,05$, it can be concluded that the price discount, sales promotion, and overall appearance in the store have a significant effect on the impulsive purchase decision at Matahari Department Store Padang. The magnitude of the influence of the independent variable on the dependent variable is $80 \%$, the remaining $20 \%$ is influenced by other variables not included in the research model.
\end{abstract}

Keywords: Discounts, Sales Promotions, Shop Display, and Impulsive Purchasing Decisions

\begin{abstract}
Abstrak : Penelitian ini bertujuan untuk mengetahui pengaruh Pengaruh Potongan Harga, Promosi Penjualan, Tampilan Dalam Toko Terhadap Keputusan Pembelian Impulsif Konsumen Matahari Departement Store Padang. Sampel yang diteliti dalam penelitian ini sebanyak 100 responden yang merupakan konsumen Matahari Departement Store Padang. Berdasarkan uji t statistik yang dilakukan maka dapat disimpulkan bahwa variabel potongan harga berpengaruh positif dan signifikan terhadap keputusan pembelian impulsif yang ditunjukkan oleh nilai signifikansi sebesar $0,047<$ alpha 0,05 . Berdasarkan uji t statistik yang dilakukan maka dapat disimpulkan bahwa promosi penjualan berpengaruh positif dan signifikan terhadap keputusan pembelian impulsif yang ditunjukkan oleh nilai signifikansi sebesar $0,000<$ alpha 0,05 . Berdasarkan uji t statistik yang dilakukan maka dapat disimpulkan bahwa tampilan dalam toko berpengaruh positif dan signifikan terhadap keputusan pembelian impulsif yang ditunjukkan oleh nilai signifikansi sebesar $0,000<$ alpha 0,05 . Berdasarkan uji f simultan diperoleh nilai signifikansi sebesar $0,000<0,05$ maka dapat disimpulkan bahwa potongan harga, promosi penjualan, dan tampilan dalam toko secara keseluruhan berpengaruh signifikan terhadap keputusan pembelian impulsif pada Matahari Departement Store Padang. Besarnya pengaruh dari variabel independen terhadap variabel dependen sebesar $80 \%$, sisanya sebesar $20 \%$ dipengaruhi oleh variabel lain yang tidak dimasukkan ke dalam model penelitian.
\end{abstract}

Kata Kunci: Potongan Harga, Promosi Penjualan, Tampilan Dalam Toko, dan Keput Pembelian Impulsif 


\section{A. PENDAHULUAN}

Dengan munculnya perusahaan e-commerce seperti Bukalapak dan Lazada dimana perusahaan tersebut mengambil pangsa pasar yang sama dari perusahaan ritel seperti Matahari Departemen Store mengakibatkan ruginya perusahaan ritel tersebut. Perubahan perilaku konsumen dari berbelanja secara konvensional melalui perusahaan-perusahaan ritel beralih ke belanja secara online pada perusahaan e-commerce dimana konsumen perusahaan ritel sebagian besar diambil alih oleh perusahaan e-commerce. Hal ini memaksa manajemen perusahaan ritel konvensional untuk melakukan berbagai macam strategi agar mampu bersaing di tengah ketatnya persaingan bisnis. Perusahaan ritel harus melakukan inovasi agar mampu menyaingi perusahaan e-commerce yang muncul secara tiba-tiba sebagai akibat dari perkembangan teknologi informasi yang semakin maju.

Pada saat ini banyak perusahaan ritel di Indonesia yang sudah menutup gerainya sebagai akibat dari munculnya perusahaan-perusahaan e-commerce dimana konsumen lebih memilih berbelanja dengan menggunakan sistem online. Manajemen perusahaan ritel membutuhkan strategi baru dalam mengembangkan usahanya sesuai dengan perkembangan bisnis digital yang dapat melibatkan faktor luar untuk pengambilan keputusan pada bisnis strategi. Perusahaan ritel juga harus membutuhkan marketing channel seperti jaringan distribusi perusahaan. Perusahaan ritel harus bisa menciptakan platform-platform digital dalam rangka mendekatkan diri kepada konsumennya secara online. Hal ini akan menjadi peluang yang sangat besar jika perusahaan ritel mampu memodifikasi sistem pemasaran berbasis online dan offline.

Strategi pemasaran yang dilakukan oleh perusahaan ritel saat ini lebih berfokus kepada menciptakan website yang dapat menyaingi perusahaan e-commerce seperti matahari menggunakan website sendiri dengan nama https://www.matahari.com. Hal tersebut dilakukan agar dapat mendekatkan diri kepada konsumen dengan memperlihatkan fitur-fitur produk yang ditawarkan oleh perusahaan. Konsumen dapat lebih leluasa untuk berbelanja di Matahari Departemen Store dengan menggunakan laptop atau smartphone, tanpa harus berbelanja ke Matahari Mall. Matahari juga menyediakan platform Android dengan nama Matahari App yang dapat diunduh melalui Google Play Store pada smartphone berbasis Android. Strategi ini dapat mengembalikan citra Matahari Departemen Store yang mulai menurun sejak munculnya perusahaan e-commerce.

Perkembangan penjualan ritel di Indonesia dapat dilihat pada grafik di bawah ini yaitu:

\section{Grafik 1. Perkembangan Penjualan Ritel di Indonesia}

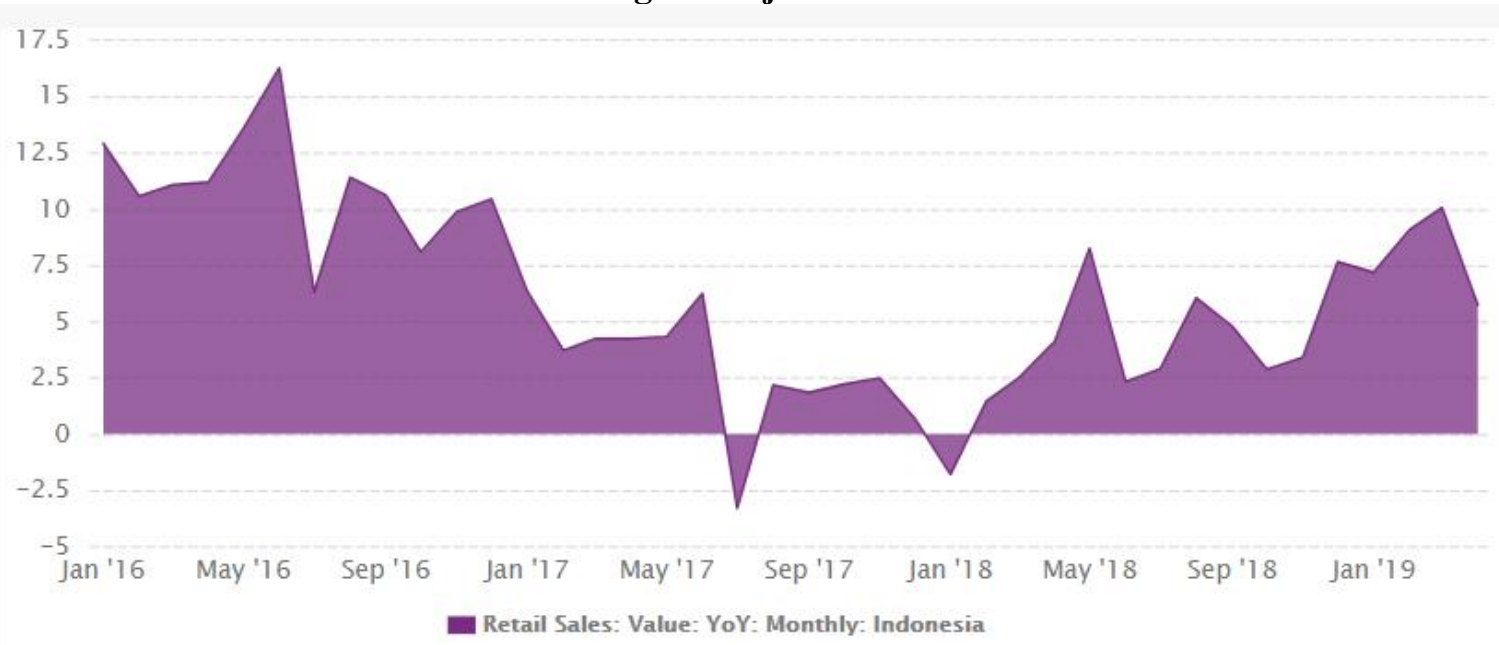

Sumber: Ceicdata, 2019

Berdasarkan gambar di atas dapat dijelaskan bahwa perkembangan penjualan ritel di Indonesia dari Januari 2016 sampai dengan Januari 2018 mengalami tren penurunan yang cukup signifikan. Hal ini terjadi karena munculnya perusahaan e-commerce seperti Bukalapak, Tokopedia, dan Lazada yang mengambil alih sebagian besar konsumen dari perusahaan ritel. 
Namun pada awal September 2018 sampai dengan Januari 2019 perusahaan ritel kembali mengalami peningkatan, dikarenakan perubahan strategi yang dilakukan oleh perusahaan ritel dimana perusahaan tersebut menggunakan website sebagai sistem pemasarannya untuk menyaingi perusahaan e-commerce. Adanya percepatan pertumbuhan perusahaan e-commerce mendorong perusahaan ritel untuk dapat melakukan inovasi secara menyeluruh. Perkembangan perusahaan ritel di Indonesia dapat dilihat pada tabel berikut ini yaitu:

Tabel 1. Perkembangan Perusahaan Ritel Terbesar di Indonesia (Persentase)

\begin{tabular}{|c|c|c|c|c|c|c|}
\hline Perusahaan Ritel & 2013 & 2014 & 2015 & 2016 & 2017 & 2018 \\
\hline Electronic City & 40,69 & 10,64 & $-20,04$ & $-6,78$ & 9,56 & 10,18 \\
\hline Sumber Alfaria Trijaya & 28,41 & 18,91 & 16,31 & 16,25 & 9,55 & 7,5 \\
\hline Ramayana & 5,28 & $-2,32$ & $-5,6$ & 5,86 & -4 & 4,8 \\
\hline Mitra Adiperka & 28,33 & 21,45 & 8,55 & 10,26 & 15,24 & 18 \\
\hline Supra Boga & 21 & 26,36 & 16,34 & 7,74 & 6,08 & 18,91 \\
\hline Hero & 13,22 & 7,3 & 12,4 & $-4,7$ & $-4,71$ & 1,1 \\
\hline Ace Hardware & 20,85 & 16,58 & 4,43 & 4,08 & 20,31 & 10 \\
\hline Midi Utama & 28,17 & 19,75 & 20,68 & 18,42 & 15,01 & 8,3 \\
\hline Matahari Departmen Store & 20,25 & 17,34 & 13,64 & 9,88 & 1,28 & $-5,4$ \\
\hline Matahari Putra Prima & 9,61 & 14,08 & 1,56 & $-1,99$ & $-7,13$ & $-12,5$ \\
\hline
\end{tabular}

Sumber: Databoks, 2019

Berdasarkan tabel di atas dapat dijelaskan bahwa perkembangan perusahaan ritel terbesar di Indonesia mengalami penurunan paling banyak terjadi pada tahun 2016 sebanyak tiga perusahaan yaitu Electronic City, Hero, dan Matahari Putra Prima. Pada tahun 2017 perusahaan ritel juga mengalami penurunan yaitu perusahaan Ramayana, Hero, dan Matahari Putra Prima. Pada tahun 2018 terdapat dua perusahaan ritel yang mengalami penurunan yaitu Matahari Departemen Store dan Matahari Putra Prima sebesar 5,4\% dan 12,5\%. Hal ini mengindikasikan bahwa masih lemahnya perkembangan perusahaan ritel di Indonesia sehingga perlu dilakukan perbaikan dan strategi baru dalam meningkatkan pemasaran perusahaan ritel tersebut.

Penelitian ini difokuskan kepada Matahari Departement Store karena sepanjang tahun 2018 terdapat dua gerai Matahari Departement Store yang ditutup karena berbagai macam alasan (Laporan Tahunan Matahari Departement Store, 2018:26). Hal ini mengindikasikan bahwa adanya penurunan terhadap bisnis Matahari Departement Store yang dapat dilihat dari perolehan laba pada tahun 2018 hanya mencapai Rp. 1.097,3 miliar dimana pada tahun 2017 telah mencapai Rp. 1.907 miliar, pada tahun 2016 mencapai Rp. 2.019,7 miliar. Hal ini mengindikasikan bahwa laba bersih Matahari Departement Store semakin lama semakin menurun dimana laba terendah terjadi pada tahun 2018. Dengan adanya permasalahan tersebut maka peneliti akan melakukan penelitian di Matahari Departement Store Padang tentang faktor apa saja yang mempengaruhi penurunan kinerja dari perusahaan tersebut yang diukur melalui bagaimana tingkat pembelian impulsif konsumennya. Sebagian besar konsumen yang berbelanja di Matahari Departement Store lebih menggunakan sistem pembelian impulsif atau secara tiba-tiba tanpa direncanakan karena adanya ketertarikan dari produk yang dipajang di perusahaan.

Pembelian impulsif adalah suatu perilaku pembelian yang dapat terbentuk di dalam toko tanpa adanya perencanaan dari konsumen sebelum memasuki toko tersebut (Clara, 2017:10). Pembelian impulsif merupakan pembelian yang dilakukan oleh konsumen secara tiba-tiba tanpa adanya perencanaan terlebih dahulu tentang kualitas atau kebutuhan dari produk tersebut. Pembelian secara impulsif sering muncul pada saat konsumen memasuki toko ritel dengan melihat bentuk dan desain produk saja sehingga memunculkan adanya ketertarikan terhadap produk tersebut (Clara, 2017:10). Ketertarikan secara spontanitas tersebut membuat 
konsumen melakukan pembelian tanpa direncanakan dan tanpa melihat kualitas atau manfaatnya di kemudian hari. Pembelian secara impulsif biasanya sangat bergantung pada citra produk atau perusahaan ritel tersebut dimana perusahaan tersebut sudah menjamin kualitas dari produk yang ditawarkan.

Indikator yang dapat dipergunakan untuk mengukur pembelian impulsif (Amanah \& Pelawi, 2015:11) adalah:

1. Konsumen merasakan adanya suatu dorongan yang tiba-tiba dan spontan untuk melakukan suatu tindakan yang berbeda dengan tingkah laku sebelumnya.

2. Dorongan tiba-tiba untuk melakukan suatu pembelian menempatkan konsumen dalam keadaan ketidakseimbangan secara psikologis, dimana untuk sementara waktu ia merasa kehilangan kendali.

3. Konsumen akan mengalami konflik psikologis dan ia berusaha untuk menimbang antara pemuasan kebutuhan langsung dan konsekuensi jangka panjang dari pembelian.

4. Konsumen akan mengurangi evaluasi kognitif dari produk.

5. Konsumen seringkali membeli secara impulsif tanpa memperhatikan konsekuensi yang akan datang.

Penurunan terhadap penjualan di Matahari Departemen Store mengindikasikan bahwa adanya penurunan terhadap pembelian impulsif konsumen di perusahaan. Pada dasarnya konsumen yang datang ke Matahari Departement Store sebagian besar melakukan pembelian secara impulsif dikarenakan adanya daya tarik terhadap desain dan produk yang dijual di perusahaan. Adanya penurunan terhadap pembelian impulsif akan menciptakan kerugian yang besar bagi perusahaan.

Salah satu faktor yang mempengaruhi pembelian impulsif adalah potongan harga yang diberikan oleh perusahaan. Potongan harga adalah pengurangan harga kepada pembeli pada waktu tertentu dengan situasi tertentu seperti pembayaran dini, pembelian volume, dan pembelian diluar musim (Kotler, 2018:92). Artinya potongan harga diberikan pada situasisituasi tertentu dimana situasi tersebut banyak menguntungkan perusahaan atau konsumen. Potongan harga juga diberikan sebagai daya tarik kepada konsumen agar mau membeli produk yang ditawarkan oleh perusahaan. Potongan harga selalu menjadi modus dalam operasi pada banyak perusahaan yang menawarkan produk dan jasanya dalam jumlah yang besar untuk dihabiskan.

Beberapa perusahaan dengan kapasitas lebih dapat berusaha memberikan potongan harga atau bahkan mulai memasok pengecer dengan versi merek toko produknya dengan potongan harga yang besar. Potongan harga hanya diberikan kepada situasi tertentu yang mendorong perusahaan untuk lebih menarik konsumen dalam berbelanja. Potongan harga tidak dapat diberikan setiap waktu karena pada dasarnya potongan harga merupakan penurunan terhadap laba perusahaan karena adanya pembayaran dari pembelian produk yang lebih murah. Namun pada kenyataannya banyak perusahaan ritel yang menaikkan harga lebih dari situasi sebelum adanya potongan harga kemudian dilakukan potongan harga sehingga terlihat perusahaan memberikan diskon kepada konsumennya. Hal ini banyak ditemukan di perusahaan ritel dimana harga awalnya seperti pada pembelian baju sebesar Rp. 100.000 kemudian dilakukan diskon sebesar 50\% pada harga Rp. 200.000. Tindakan seperti ini akan sangat berbahaya bagi perusahaan jika konsumen mengetahui harga dasarnya sebelum situasi dilakukannya potongan harga.

Menurut Stanton mendefinisikan potongan harga adalah hasil dari pengurangan pada harga dasar atau harga yang tercatat pengurangan yang dapat berbentuk harga dipotong atau konsumsi lain seperti sejumlah barang gratis (Kristiawan, 2018:32). Potongan harga juga didefinisikan sebagai pengurangan terhadap harga pada label produk dimana harga pada label lebih tinggi dari harga yang dibayarkan oleh konsumen. Artinya konsumen melakukan pembayaran dengan harga yang lebih rendah dari yang tertera dilabel produk karena adanya potongan harga yang diberikan kepada konsumen tersebut.

Indikator yang dapat digunakan untuk mengukur baik atau tidaknya potongan harga (Kristiawan, 2018) yaitu:

1. Memicu konsumen membeli dalam jumlah banyak

2. Mengantisipasi promosi pesaing 
3. Mendukung perdagangan dalam jumlah yang lebih besar

Menurut laporan tahunan Matahari Departement Store tahun 2018 menjelaskan bahwa perusahaan selalu memberikan potongan harga 50\% namun tidak mampu menaikkan penjualan perusahaan secara signifikan. Hal ini mengindikasikan bahwa perusahaan harus lebih memaksimalkan potongan harga sehingga akan mampu menciptakan pembelian impulsif yang lebih baik untuk meningkatkan penjualan dan mendapatkan laba yang signifikan.

Salah satu faktor yang mempengaruhi pembelian impulsif adalah promosi penjualan yang dilakukan oleh perusahaan. Promosi penjualan adalah suatu bahan inti dari kampanye pemasaran yang terdiri dari koleksi alat insentif dimana sebagian besar dalam jangka pendek yang dirancang untuk menstimulasi pembelian yang lebih cepat atau lebih besar atas produk dan jasa tertentu oleh konsumen atau perdagangan (Kotler, 2018:219). Promosi penjualan merupakan suatu tindakan yang dilakukan oleh perusahaan dalam rangka mempercepat penjualan terhadap produk yang ditawarkan kepada konsumen melalui cara-cara tertentu yang disepakati oleh perusahaan tersebut. Alat promosi penjualan adalah sampel, kupon, percobaan gratis, penawaran pengembalian dana tunai, hadiah, penghargaan promosi yang berkaitan promosi silang, tampilan pembelian, dan demonstrasi. Tujuan dari promosi penjualan adalah mendorong konsumen untuk melakukan pembelian agar terjaganya hubungan jangka panjang antara konsumen dengan perusahaan.

Matahari Departement Store hanya melakukan promosi dengan memanfaatkan karyawannya untuk melakukan promosi kepada konsumen yang datang ke toko tersebut. Hal ini dilakukan untuk meminimalisir biaya karena promosi yang dilakukan di media massa memiliki biaya yang cukup mahal dengan keadaan perusahaan yang mengalami penjualan yang semakin menurun tidak memungkinkan untuk melakukannya. Matahari Departement Store harus mampu memaksimalkan promosi penjualan yang dilakukan di perusahaan atau dengan menggunakan website perusahaan karena telah beralih kepada sistem promosi melalui transaksi e-commerce. Namun hal ini belum mampu meningkatkan laba perusahaan karena transaksi ecommerce yang dilakukan oleh Matahari Departement Store masih tergolong baru dan masyarakat masih belum banyak yang mengetahui tentang adanya e-commerce yang dilakukan oleh perusahaan ini.

Indikator-indikator promosi penjualan diantaranya (Amanah \& Pelawi, 2015) adalah:

1. Frekuensi promosi adalah jumlah promosi penjualan yang dilakukan dalam suatu waktu melalui media promosi penjualan.

2. Kualitas promosi adalah tolak ukur seberapa baik promosi penjualan dilakukan.

3. Kuantitas promosi adalah nilai atau jumlah promosi penjualan yang diberikan konsumen.

4. Waktu promosi adalah berapa lama promosi penjualan yang dilakukan oleh perusahaan.

5. Ketepatan atau kesesuaian sasaran promosi merupakan faktor yang diperlukan untuk mencapai target yang diinginkan perusahaan.

Salah satu faktor yang mempengaruhi pembelian impulsif adalah tampilan dalam toko. Tampilan dalam toko adalah penyediaan informasi kepada pembeli penambahan atmosfer toko dan pelayanan yang berperan dalam promosi dalam skala besar (Kristiawan, 2018:34). Tampilan dalam toko merupakan bentuk tampilan untuk mempromosikan produk dan jasa kepada konsumen agar mereka dapat dengan mudah menemukan produk yang menarik untuk dilakukan pemilihan. Tampilan dalam toko didesain semenarik mungkin agar konsumen tertarik melakukan pembelian secara tiba-tiba atau impulsif karena tampilan dalam tokoh merupakan rangsangan utama dalam menentukan apakah konsumen akan melakukan pembelian atau tidak. Sistem pembelian yang direncanakan sekalipun jika tampilan tokohnya tidak memadai maka konsumen tidak akan tertarik melakukan pembelian meskipun telah direncanakan sebelumnya. Apalagi sistem pembelian impulsif dimana tampilan dalam toko merupakan faktor utama yang mempengaruhi pembelian konsumen secara impulsif. Indikator yang dipergunakan untuk mengukur tampilan dalam toko (Kristiawan, 2018) yaitu:

1. Letak produk yang mudah dijangkau dan menarik akan menjadi alasan konsumen untuk membeli merek tersebut.

2. Konsumen lebih sering membeli merek yang menyiapkan tampilan dalam toko (contoh: tampilan rak) yang menarik dan letak produknya mudah dijangkau. 
Contoh bentuk tampilan dalam toko Matahari Departemen Store Padang dapat dilihat pada gambar berikut ini yaitu:

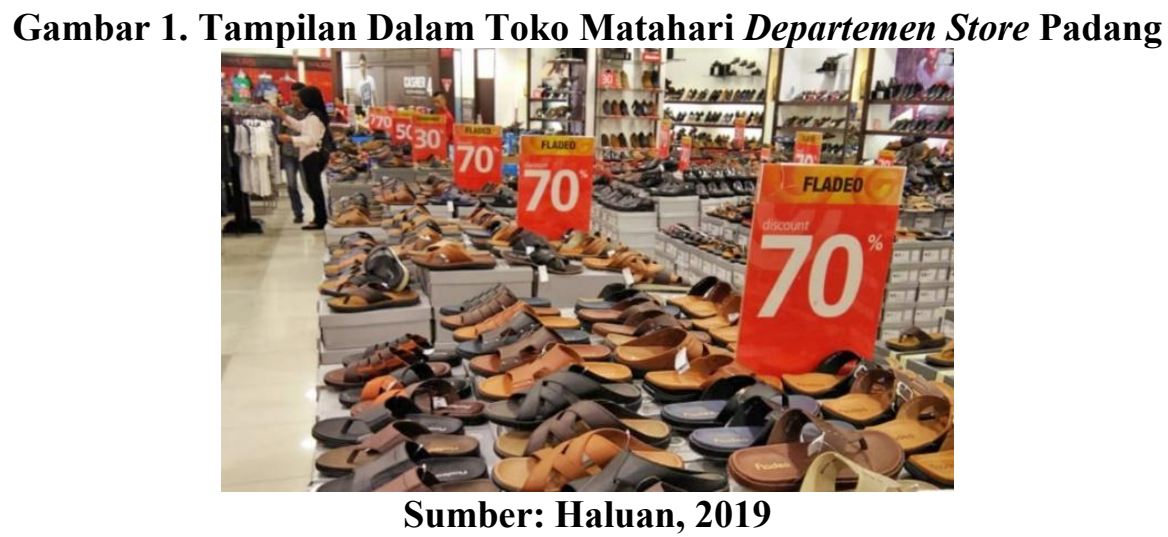

Berdasarkan gambar di atas dapat dijelaskan bahwa tampilan dalam toko pada Matahari Departement Store Padang di desain sangat menarik dengan strategi tertentu dimana produk dikelompokkan berdasarkan jenisnya dengan potongan harga yang mencapai $70 \%$. Namun strategi ini belum mampu meningkatkan penjualan dan laba perusahaan secara signifikan yang terlihat dari menurunnya laba secara keseluruhan. Untuk itu perlu dilakukan analisa lebih lanjut tentang dampak desain toko terhadap keputusan pembelian secara tiba-tiba atau impulse pada perusahaan.

Untuk lebih jelasnya kerangka penelitian ini digambarkan pada gambar 2 berikut:

\section{Gambar 2. Kerangka Penelitian}

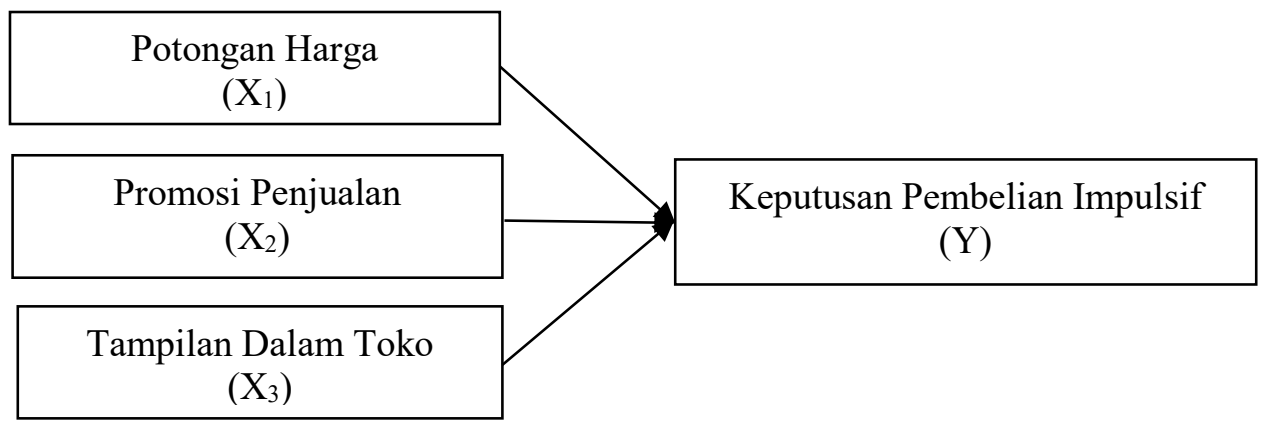

Sumber : Clara (2017)

Berdasarkan kerangka penelitian yang telah disajikan tersebut teori-teori pendukung yang telah dipaparkan sebelumnya maka penulis merumuskan 2 hipotesis dalam penelitian ini yaitu:

H1: Diduga potongan harga berpengaruh signifikan terhadap keputusan pembelian impulsif konsumen Matahari Departement Store Padang.

H2: Diduga promosi penjualan berpengaruh signifikan terhadap keputusan pembelian impulsif konsumen Matahari Departement Store Padang.

H3: Diduga tampilan dalam toko berpengaruh signifikan terhadap keputusan pembelian impulsif konsumen Matahari Departement Store Padang.

\section{B. METODOLOGI PENELITIAN}

Untuk mendapatkan data keterangan yang diperlukan dalam penyusunan laporan maka penulis menggunakan kuesioner. Kuesioner adalah bentuk metode pengumpulan data dengan memberikan daftar pertanyaan kepada para konsumen perusahaan sebagai responden, dengan 
harapan mereka memberikan respons atas daftar pertanyaan tersebut. Sedangkan untuk jenis data yang digunakan dalam penelitian ini adalah data kualitatif dan kuantitatif. Dengan sumber data primer dan sekunder.

Yang menjadi populasi dalam penelitian ini adalah seluruh konsumen Matahari Departement Store yang tidak diketahui jumlahnya. . Jika populasinya besar maka peneliti tidak mungkin mempelajari semua yang ada pada populasi, hal ini terjadi karena keterbatasan dana, tenaga, dan waktu. Maka peneliti dapat menggunakan sampel yang diambil dari populasi itu (Sugiyono, 2017:62). Adapun rumus Cochran yang dipergunakan dalam penelitian ini yaitu:

$$
n=\frac{Z^{2} p q}{e^{2}}
$$

Dimana:

$\mathrm{n}=$ Jumlah sampel

$\mathrm{Z}=$ Standar skor untuk $\infty$ yang di pilih $(1,96)$

$\mathrm{P}=$ Proporsi estimasi dari kejadian pada populasi $(0,5)$

$\mathrm{q}=1-\mathrm{p}(1-0,5=0,5)$

$\mathrm{e}=$ Standar deviasi/kelonggaran $(10 \%)$

Sehingga bila memakai rumus Cochran, maka jumlah sampel dalam penelitian ini adalah sebagai berikut:

$$
n=\frac{(1,96)^{2}(0,5)(0,5)}{(0,1)^{2}}
$$

= 96,04 Untuk kepentingan peneliti maka jumlah sampel ditetapkan menjadi 100 orang. Maka jumlah sampel dalam penelitian ini adalah sebanyak 100 responden penelitian. Metode pemilihan sampel yang dipergunakan adalah dengan menggunakan teknik incidental sampling. Teknik incidental sampling adalah teknik penentuan sampel berdasarkan kebetulan, yaitu siapa saja yang secara kebetulan atau insidental bertemu dengan peneliti dapat digunakan sebagai sampel, bila dipandang orang yang kebetulan ditemui itu cocok sebagai sumber data (Sugiyono, 2017:67). Sampel dalam penelitian ini adalah siapa saja konsumen Matahari Departement Store Padang yang pernah berbelanja pada saat dilakukan penelitian maka dianggap sebagai sampel.

Sebelum melakukan analisis regresi, perlu dilakukan pengujian analisis data terlebih dahulu, agar data sampel yang diolah benar-benar dapat mewakili populasi secara keseluruhan. Adapun uji asumsi klasik yang digunakan sebagai berikut:

\section{Uji Normalitas}

Pengujian normalitas bertujuan untuk menguji apakah dalam model regresi terdapat variabel pengganggu atau residual. Untuk pengujian uji parsial dan simultan harus mengasumsikan bahwa nilai residual mengikuti distribusi normal. Jika asumsi ini dilanggar maka uji statistik menjadi tidak valid untuk jumlah sampel kecil (Ghozali, 2017:127). Uji normalitas data dalam penelitian ini dengan menggunakan alat uji One Sample Kolmogorov Smirnov Test. Uji One Sample Kolmogorov Smirnov Test dapat ditentukan apabila nilai asymp. sig (2-tailed) lebih besar dari alpha 0,05 maka data dapat dikatakan telah terdistribusi normal (Ghozali, 2017:132).

\section{Uji Multikolinearitas}

Uji Multikolinieritas adalah uji yang dilakukan untuk menguji adanya korelasi antar variabel indpenden. Pada model regresi yang baik seharusnya tidak terjadi korelasi antara variabel independen. Jika variabel independen saling berkorelasi, maka variabel tersebut dikatakan tidak ortogonal. Variabel ortogonal adalah variabel indpenden sama dengan nol. Untuk dapat mendeteksi ada atau tidaknya multikolinieritas yang terdapat dalam model regresi adalah dengan cara melihat nilai variance inflation factor (VIF). Apabila nilai VIF lebih besar dari 10, maka dalam hal ini terjadi multikolinieritas data (Ghozali, 2017). 


\section{Uji Heteroskedastisitas}

Pengujian heteroskedastisitas dapat dilakukan dengan menggunakan metode grafik atau yang lebih dikenal dengan scatterplot. Metode ini dilakukan dengan melihat pola grafik plot antara nilai prediksi variabel dependen dengan residualnya. Deteksi ada atau tidaknya heteroskedastisitas dapat dilakukan dengan melihat ada tidaknya pola tertentu pada grafik scatterplot dimana plot menyebar secara tidak beraturan, maka dapat dikatakan uji heteroskedastisitas telah terpenuhi (Ghozali, 2017:49).

Sedangkan untuk pengujian hipotesis akan dimulai dari persamaan regresi dan dilanjutkan dengan uji lainnya. Dengan rincian sebagai berikut:

\section{Analisis Regresi Berganda}

Metode yang digunakan dalam penelitian ini adalah analisis regresi linear berganda untuk melihat perubahan dari nilai variabel dependen jika terdapat variabel independen serta perubahan nilai variabel dependen tanpa adanya variabel dependen (Sugiyono, 2017:275). Rumus yang digunakan adalah:

$\begin{array}{ll}\mathrm{Y}=\mathrm{a}+\mathrm{b}_{1} \mathrm{X}_{1}+\mathrm{b}_{2} \mathrm{X}_{2}+\mathrm{b}_{3} \mathrm{X}_{3}+\mathrm{e} \\ \text { Dimana: } & : \text { Keputusan Pembelian Impulsif } \\ \mathrm{Y} & : \text { Konstanta } \\ \mathrm{a} & : \text { Koefisien } \mathrm{x} \\ \mathrm{b}_{1}, \mathrm{~b}_{2}, \text { dan } \mathrm{b}_{3} & \text { Potongan Harga } \\ \mathrm{X}_{1} & : \text { Promosi Penjualan } \\ \mathrm{X}_{2} & \text { :Tampilan Dalam Toko } \\ \mathrm{X}_{3} & : \text { error } \\ \mathrm{e} & \end{array}$

\section{Uji t Statistik}

: error

Jika asumsi normalitas terpenuhi maka dapat menggunakan uji t untuk menguji koefisien parsial dari regresi (Ghozali, 2017:23). Kriteria dalam pengujian uji t parsial apabila terpenuhi adalah:

1. Apabila nilai signifikansi lebih kecil dari pada tingkat alpha 0,05 maka dapat dikatakan hipotesis alternatif diterima dan menolak hipotesis nol.

2. Apabila nilai signifikansi lebih besar dari tingkat alpha 0,05 maka dapat dikatakan 3. Uji f Simultan hipotesis alternatif di tolak dan menerima hipotesis nol.

Pengujian hipotesis ini disebut juga dengan pengujian signifikansi bersamaan (overall significance) terhadap garis regresi yang ingin menguji apakah variabel dependen secara linear berhubungan dengan seluruh variabel independen. Hubungan hipotesis dapat diuji dengan teknik analisis variance pada tabel anova (Ghozali, 2017:22). Kriteria dalam pengujian uji $\mathrm{f}$ simultan apabila terpenuhi adalah:

1. Apabila nilai signifikansi lebih kecil dari pada tingkat alpha 0,05 maka dapat dikatakan hipotesis alternatif diterima dan menolak hipotesis nol.

2. Apabila nilai signifikansi lebih besar dari pada tingkat alpha 0,05 maka dapat dikatakan hipotesis alternatif di tolak dan menerima hipotesis nol.

\section{Koefisien Determinasi $\left(\mathbf{R}^{2}\right)$}

Uji koefisien determinasi pada intinya mengukur seberapa jauh kemampuan model dalam menerangkan variasi variabel dependen. Nilai koefisien determinasi adalah antara 0 dan 1. Nilai $\mathrm{R}^{2}$ yang kecil berarti kemampuan variabel-variabel independen dalam menjelaskan variasi variabel dependen amat terbatas. Nilai yang mendekati satu berarti variabel-variabel independen memberikan hampir semua informasi yang dibutuhkan untuk memprediksi variasi variabel dependen (Ghozali, 2017:21). 
C. PEMBAHASAN

Hasil Uji Asumsi Klasik

1. Uji Normalitas Data

Hasil pengujian dan pengolahan data tersebut dapat dilihat pada tabel 2 berikut ini:

Tabel 2. Hasil Uji Normalitas

One-Sample Kolmogorov-Smirnov Test

\begin{tabular}{|c|c|c|c|c|c|}
\hline & & $\begin{array}{c}\text { Keputusan Pembelian } \\
\text { Impulsif }\end{array}$ & $\begin{array}{l}\text { Potongan } \\
\text { Harga }\end{array}$ & $\begin{array}{l}\text { Promosi } \\
\text { Penjualan }\end{array}$ & $\begin{array}{l}\text { Tampilan } \\
\text { Dalam Toko }\end{array}$ \\
\hline \multicolumn{2}{|l|}{$\mathrm{N}$} & 100 & 100 & 100 & 100 \\
\hline Normal & Mean & 16.3800 & 16.7100 & 17.4700 & 17.2000 \\
\hline Parameters ${ }^{\mathrm{a}, \mathrm{b}}$ & Std. Deviation & 4.31764 & 4.81432 & 3.99104 & 3.84550 \\
\hline Most Extreme & Absolute & .084 & .086 & .086 & .082 \\
\hline Differences & Positive & .084 & .052 & .063 & .077 \\
\hline & Negative & -.069 & -.086 & -.086 & -.082 \\
\hline Test Statistic & & .084 & .086 & .086 & .082 \\
\hline Asymp. Sig. (2 & ailed) & $.081^{\mathrm{c}}$ & $.068^{\mathrm{c}}$ & $.064^{\mathrm{c}}$ & $.091^{\mathrm{c}}$ \\
\hline
\end{tabular}

a. Test distribution is Normal.

b. Calculated from data.

c. Lilliefors Significance Correction.

Sumber : Hasil Pengolahan, 2019

Dari hasil perhitungan uji Kolmogorov Smirnov pada tabel 2 di atas dapat diketahui bahwa variabel potongan harga bernilai asymp.sig (2-tailed) sebesar 0,068 $>0,05$, variabel promosi penjualan bernilai asymp.sig (2-tailed) sebesar 0,064 >0,05, variabel tampilan dalam toko bernilai asymp.sig (2-tailed) sebesar 0,091 >0,05, dan variabel keputusan pembelian impulsif bernilai asymp.sig (2-tailed) sebesar 0,081 >0,05 sehingga dapat disimpulkan bahwa keseluruhan data tersebut dinyatakan memiliki distribusi normal atau memiliki sebaran data yang normal.

\section{Uji Multikolinearitas}

Hasil pengujian multikolinearitas dapat dilihat pada tabel3 berikut ini:

Tabel 3. Uji Multikolineritas

Coefficients $^{\mathrm{a}}$

\begin{tabular}{|ll|r|c|}
\hline \multirow{2}{*}{ Model } & \multicolumn{2}{|c|}{ Collinearity Statistics } \\
\cline { 3 - 4 } & (Colerance & \multicolumn{1}{c|}{ VIF } \\
\hline 1 & Potongant) Harga & .345 & \\
& Promosi Penjualan & .352 & 2.901 \\
& & 2.840 \\
& Tampilan Dalam Toko & .325 & 3.073 \\
\hline
\end{tabular}

a. Dependent Variable: Keputusan Pembelian Impulsif

Sumber: Hasil Pengolahan, 2019

Dari tabel 3 di atas menunjukkan bahwa nilai VIF untuk variabel potongan harga sebesar $2,901<10$ dan nilai tolerance sebesar 0,345 >0,1 sehingga dapat disimpulkan bahwa tidak terjadi gejala multikolinearitas. Nilai VIF untuk variabel promosi penjualan sebesar 2,840 $<10$ dan nilai tolerance sebesar 0,352 >0,1 sehingga dapat disimpulkan bahwa tidak terjadi gejala multikolinearitas. Nilai VIF untuk variabel tampilan dalam toko sebesar 3,073<10 dan nilai tolerance sebesar $0,325>0,1$ sehingga dapat disimpulkan bahwa tidak terjadi gejala multikolinearitas antara variabel bebas dalam model regresi. 


\section{Uji Heteroskedastisitas}

Hasil uji heteroskedastisitas menggunakan model grafis seperti yang terlihat pada gambar 3 berikut ini:

Gambar 3. Hasil Uji Heteroskedastisitas

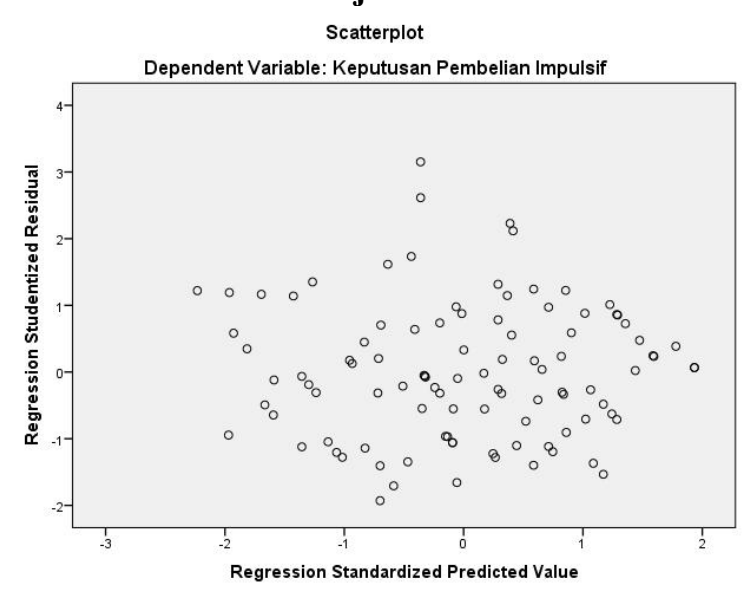

Sumber: Hasil Pengolahan Data SPSS 23, 2019

Berdasarkan gambar 3 dapat dijelaskan bahwa tidak ada pola tertentu karena titik menyebar tidak beraturan di atas dan di bawah sumbu 0 pada sumbu Y. Maka dapat disimpulkan tidak terdapat gejala heteroskedastisitas.

\section{Pengujian Hipotesis}

1. Analisis Regresi Linear Berganda

Hasil uji regresi linear berganda dapat dilihat pada tabel 4, yaitu:

Tabel 4. Hasil Analisis Data Untuk Persamaan Regresi Linear Berganda Coefficients ${ }^{\mathrm{a}}$

\begin{tabular}{|c|c|c|c|c|c|}
\hline \multirow[b]{2}{*}{ Model } & \multicolumn{2}{|c|}{$\begin{array}{l}\text { Unstandardized } \\
\text { Coefficients }\end{array}$} & \multirow{2}{*}{$\begin{array}{c}\begin{array}{c}\text { Standardized } \\
\text { Coefficients }\end{array} \\
\text { Beta }\end{array}$} & \multirow[b]{2}{*}{$\mathrm{t}$} & \multirow[b]{2}{*}{ Sig. } \\
\hline & $\mathrm{B}$ & Std. Error & & & \\
\hline (Constant) & -1.514 & .942 & & -1.608 & 111 \\
\hline Potongan Harga & .138 & .069 & .154 & 2.011 & .047 \\
\hline Promosi Penjualan & .300 & .082 & 277 & 3.663 & .000 \\
\hline Tampilan Dalam Toko & .601 & .088 & .536 & 6.798 & .000 \\
\hline
\end{tabular}

a. Dependent Variable: Keputusan Pembelian Impulsif

\section{Sumber: Hasil Pengolahan, 2019}

Berdasarkan tabel4 di atas, maka bentuk persamaan regresinya adalah sebagai berikut:

$$
\mathrm{Y}=-1,514+0,138 \quad X_{1}+0,300 \quad X_{2}+0,601 \quad X_{3}+\mathrm{e}
$$

Persamaan regresi di atas dapat dijelaskan sebagai berikut:

1. Nilai konstanta adalah $-1,514$ artinya jika tidak memperhatikan variabel potongan harga, promosi penjualan, dan tampilan dalam toko (bernilai nol) maka keputusan pembelian impulsif mengalami penurunan sebesar 1,514.

2. Nilai koefisien regresi potongan harga adalah positif 0,138 artinya potongan harga berbanding lurus/searah dengan keputusan pembelian impulsif dimana setiap peningkatan 1 satuan potongan harga maka akan meningkatkan keputusan pembelian impulsif sebesar 0,138. Demikian juga sebaliknya jika terjadi penurunan.

3. Nilai koefisien regresi promosi penjualan adalah positif 0,300 artinya promosi penjualan berbanding lurus/searah dengan keputusan pembelian impulsif dimana setiap peningkatan 1 satuan promosi penjualan maka akan meningkatkan keputusan pembelian impulsif sebesar 0,300 . Demikian juga sebaliknya jika terjadi penurunan.

4. Nilai koefisien regresi tampilan dalam toko adalah positif 0,601 artinya tampilan dalam toko berbanding lurus/searah dengan keputusan pembelian impulsif dimana setiap 
peningkatan 1 satuan tampilan dalam toko maka akan meningkatkan keputusan

\section{Uji t-Statistik}

pembelian impulsif sebesar 0,601. Demikian juga sebaliknya jika terjadi penurunan.

Berdasarkan hasil pengolahan data yang telah dilakukan diperoleh ringkasan hasil terlihat pada tabel 5 di bawah ini:

Tabel 5 .Uji t Statistik

Coefficients $^{\mathrm{a}}$

\begin{tabular}{|c|c|c|c|c|c|}
\hline \multirow[b]{2}{*}{ Model } & \multicolumn{2}{|c|}{$\begin{array}{c}\text { Unstandardized } \\
\text { Coefficients }\end{array}$} & \multirow{2}{*}{$\begin{array}{c}\begin{array}{c}\text { Standardized } \\
\text { Coefficients }\end{array} \\
\text { Beta }\end{array}$} & \multirow[b]{2}{*}{$\mathrm{t}$} & \multirow[b]{2}{*}{ Sig. } \\
\hline & $\mathrm{B}$ & Std. Error & & & \\
\hline $1 \quad$ (Constant) & -1.514 & .942 & & -1.608 & .111 \\
\hline Potongan Harga & .138 & .069 & .154 & 2.011 & .047 \\
\hline Promosi Penjualan & .300 & .082 & 277 & 3.663 & .000 \\
\hline Tampilan Dalam Toko & .601 & .088 & .536 & 6.798 & .000 \\
\hline
\end{tabular}

a. Dependent Variable: Keputusan Pembelian Impulsif

Sumber: Hasil Pengolahan, 2019

Berdasarkan hasil pengujian hipotesis pertama seperti terlihat pada tabel 5 terlihat bahwa potongan harga memperlihatkan nilai signifikansi sebesar $0,047<$ alpha 0,05 maka keputusannya adalah Ho ditolak dan Ha diterima. Adapun kesimpulan yang diperoleh menyatakan bahwa variabel potongan harga berpengaruh positif dan signifikan terhadap keputusan pembelian impulsif.

Berdasarkan hasil pengujian hipotesis ke dua seperti terlihat pada tabel 5 terlihat bahwa promosi penjualan memperlihatkan nilai signifikansi sebesar $0,000<$ alpha 0,05 maka keputusannya adalah Ho ditolak dan Ha diterima. Adapun kesimpulan yang diperoleh menyatakan bahwa variabel promosi penjualan berpengaruh positif dan signifikan terhadap keputusan pembelian impulsif.

Berdasarkan hasil pengujian hipotesis ke tiga seperti terlihat pada tabel 5 terlihat bahwa tampilan dalam toko memperlihatkan nilai signifikansi sebesar $0,000<$ alpha 0,05 maka keputusannya adalah Ho ditolak dan Ha diterima. Adapun kesimpulan yang diperoleh menyatakan bahwa variabel tampilan dalam toko berpengaruh positif dan signifikan terhadap keputusan pembelian impulsif.

\section{Uji f Statistik}

Hasil pengolahan data yang telah dilakukan dapat dilihat pada tabel 6 adalah:

Tabel 6. Uji f Statistik

ANOVA $^{\mathrm{a}}$

\begin{tabular}{|ll|r|r|r|r|r|}
\hline \multicolumn{2}{|l|}{ Model } & \multicolumn{1}{|c|}{$\begin{array}{c}\text { Sum of } \\
\text { Squares }\end{array}$} & df & Mean Square & F & Sig. \\
\hline 1 & Regression & 1487.602 & 3 & 495.867 & 132.986 & $.000^{\mathrm{b}}$ \\
& Residual & 357.958 & 96 & 3.729 & & \\
& Total & 1845.560 & 99 & & & \\
\hline
\end{tabular}

a. Dependent Variable: Keputusan Pembelian Impulsif

b. Predictors: (Constant), Tampilan Dalam Toko, Promosi Penjualan, Potongan Harga

Sumber: Hasil Pengolahan, 2019

Pada tabel 6 di atas terlihat nilai signifikan yang diperoleh di dalam tahapan pengujian data adalah sebesar $0,000<0,05$ maka keputusannya adalah $\quad H_{0}$ ditolak dan $H_{a}$ diterima. Adapun kesimpulan yang diperoleh menyatakan bahwa potongan harga, promosi penjualan, dan tampilan dalam toko secara keseluruhan/bersama-sama berpengaruh signifikan terhadap keputusan pembelian impulsif pada Matahari Departement Store Padang.

\section{Uji Koefisiesi Determinasi $\left(R^{2}\right)$}

Hasil pengujian koefisien determinasi penelitian ini dapat dilihat pada hasil pengolahan data pada tabel 7 berikut: 
Tabel 7. Koefisien Determinasi Model Summary ${ }^{b}$

\begin{tabular}{|l|r|r|r|r|}
\hline Model & R & R Square & $\begin{array}{c}\text { Adjusted R } \\
\text { Square }\end{array}$ & $\begin{array}{c}\text { Std. Error of } \\
\text { the Estimate }\end{array}$ \\
\hline 1 & $.898^{\mathrm{a}}$ & .806 & .800 & 1.93099 \\
\hline
\end{tabular}

a. Predictors: (Constant), Tampilan Dalam Toko, Promosi

Penjualan, Potongan Harga

b. Dependent Variable: Keputusan Pembelian Impulsif

Sumber: Hasil Pengolahan, 2019

Berdasarkan hasil pengolahan data pada tabel 7 diketahui bahwa nilai adjusted $R^{2}$ square adalah sebesar 0,800 . Hal ini berarti besarnya pengaruh dari variabel independen terhadap variabel dependen sebesar $80 \%$, sisanya sebesar $20 \%$ dipengaruhi oleh variabel lain yang tidak dimasukkan ke dalam model penelitian.

\section{Pengaruh Potongan Harga Terhadap Keputusan Pembelian Impulsif}

Hipotesis dalam penelitian ini adalah diduga potongan harga berpengaruh signifikan terhadap keputusan pembelian impulsif. Berdasarkan hasil uji regresi linear berganda dapat dijelaskan bahwa setiap peningkatan satu satuan potongan harga maka akan meningkatkan keputusan pembelian impulsif. Hasil ini didukung oleh hasil uji t parsial dimana potongan harga berpengaruh positif dan signifikan terhadap keputusan pembelian impulsif.

Hasil penelitian ini didukung oleh penelitian sebelumnya yang dilakukan oleh Kristiawan (2018) menyimpulkan bahwa potongan harga berpengaruh signifikan terhadap keputusan pembelian impulsif. Potongan harga atau diskon merupakan salah satu daya tarik yang selalu dipergunakan oleh Matahari Departement Store untuk meningkatkan pembelian secara impulsif karena dengan adanya potongan harga konsumen akan merasa membeli produk dengan harga yang lebih murah. Hal tersebut akan menciptakan pembelian secara impulsif karena adanya ketertarikan dengan harga murah.

Potongan harga adalah pengurangan harga kepada pembeli pada waktu tertentu dengan situasi tertentu seperti pembayaran dini, pembelian volume, dan pembelian diluar musim (Kotler, 2018:92). Artinya potongan harga diberikan pada situasi-situasi tertentu dimana situasi tersebut banyak menguntungkan perusahaan atau konsumen. Potongan harga juga diberikan sebagai daya tarik kepada konsumen agar mau membeli produk yang ditawarkan oleh perusahaan. Potongan harga selalu menjadi modus dalam operasi pada banyak perusahaan yang menawarkan produk dan jasanya dalam jumlah yang besar untuk dihabiskan. Beberapa perusahaan dengan kapasitas lebih dapat berusaha memberikan potongan harga atau bahkan mulai memasok pengecer dengan versi merek toko produknya dengan potongan harga yang besar. Potongan harga hanya diberikan kepada situasi tertentu yang mendorong perusahaan untuk lebih menarik konsumen dalam berbelanja. Potongan harga tidak dapat diberikan setiap waktu karena pada dasarnya potongan harga merupakan penurunan terhadap laba perusahaan karena adanya pembayaran dari pembelian produk yang lebih murah.

\section{Pengaruh Promosi Penjualan Terhadap Keputusan Pembelian Impulsif}

Hipotesis dalam penelitian ini adalah diduga promosi penjualan berpengaruh signifikan terhadap keputusan pembelian impulsif. Berdasarkan hasil uji regresi linear berganda dapat dijelaskan bahwa setiap peningkatan satu satuan promosi penjualan maka akan meningkatkan keputusan pembelian impulsif. Hasil ini didukung oleh hasil uji t parsial dimana promosi penjualan berpengaruh positif dan signifikan terhadap keputusan pembelian impulsif.

Hasil penelitian ini didukung oleh penelitian sebelumnya yang dilakukan oleh (Amanah \& Pelawi, 2015), (Clara, 2017), (Viona, 2018), dan (Melysa, 2018) menyimpulkan bahwa promosi penjualan berpengaruh signifikan terhadap keputusan pembelian impulsif. Promosi penjualan merupakan penyampaian informasi yang dilakukan oleh perusahaan kepada konsumennya, baik dilakukan secara langsung seperti penyampaian informasi oleh para 
karyawan perusahaan ataupun dengan cara tidak langsung seperti iklan sehingga dapat menarik konsumen untuk melakukan pembelian secara impulsif.

Promosi penjualan adalah suatu bahan inti dari kampanye pemasaran yang terdiri dari koleksi alat insentif dimana sebagian besar dalam jangka pendek yang dirancang untuk menstimulasi pembelian yang lebih cepat atau lebih besar atas produk dan jasa tertentu oleh konsumen atau perdagangan (Kotler, 2018:219). Promosi penjualan merupakan suatu tindakan yang dilakukan oleh perusahaan dalam rangka mempercepat penjualan terhadap produk yang ditawarkan kepada konsumen melalui cara-cara tertentu yang disepakati oleh perusahaan tersebut. Alat promosi penjualan adalah sampel, kupon, percobaan gratis, penawaran pengembalian dana tunai, hadiah, penghargaan promosi yang berkaitan promosi silang, tampilan pembelian, dan demonstrasi. Tujuan dari promosi penjualan adalah mendorong konsumen untuk melakukan pembelian agar terjaganya hubungan jangka panjang antara konsumen dengan perusahaan. Promosi penjualan di pasar sangat memiliki kemiripan yang tinggi pada merek yang dapat menghasilkan respon penjualan yang juga tinggi dalam jangka pendek akan tetapi terdapat sedikit keuntungan secara permanen pada preferensi merek dalam jangka waktu yang panjang. Semakin besar promosi yang diberikan maka akan semakin besar pembelian impulsif yang terjadi.

\section{Pengaruh Tampilan Dalam Toko Terhadap Keputusan Pembelian Impulsif}

Hipotesis dalam penelitian ini adalah diduga tampilan dalam toko berpengaruh signifikan terhadap keputusan pembelian impulsif. Berdasarkan hasil uji regresi linear berganda dapat dijelaskan bahwa setiap peningkatan satu satuan tampilan dalam toko maka akan meningkatkan keputusan pembelian impulsif. Hasil ini didukung oleh hasil uji t parsial dimana tampilan dalam toko berpengaruh positif dan signifikan terhadap keputusan pembelian impulsif.

Hasil penelitian ini didukung oleh penelitian sebelumnya yang dilakukan oleh (Kristiawan, 2018), (Sari, 2018), dan (Viona, 2018) menyimpulkan bahwa tampilan dalam toko berpengaruh signifikan terhadap keputusan pembelian impulsif. Tampilan dalam tampilan dalam tokoh yang berbentuk elegan akan menghasilkan rasa nyaman bagi konsumen sehingga konsumen merasakan ketenangan dalam melakukan pembelanjaan. Rasa nyaman tersebut akan meningkatkan pembelian secara impulsif.

Menurut Berman menjelaskan tampilan dalam toko adalah penyediaan informasi kepada pembeli penambahan atmosfer toko dan pelayanan yang berperan dalam promosi dalam skala besar (Kristiawan, 2018:34). Tampilan dalam toko merupakan bentuk tampilan untuk mempromosikan produk dan jasa kepada konsumen agar mereka dapat dengan mudah menemukan produk yang menarik untuk dilakukan pemilihan. Tampilan dalam toko didesain semenarik mungkin agar konsumen tertarik melakukan pembelian secara tiba-tiba atau impulsif karena tampilan dalam tokoh merupakan rangsangan utama dalam menentukan apakah konsumen akan melakukan pembelian atau tidak. Sistem pembelian yang direncanakan sekalipun jika tampilan tokohnya tidak memadai maka konsumen tidak akan tertarik melakukan pembelian meskipun telah direncanakan sebelumnya. Apalagi sistem pembelian impulsif dimana tampilan dalam toko merupakan faktor utama yang mempengaruhi pembelian konsumen secara impulsif. Semakin menarik tampilan dalam toko maka akan semakin besar pembelian impulsif yang terjadi.

\section{KESIMPULAN}

Berdasarkan hasil dari penelitian yang telah dilakukan, maka dapat dikemukakan beberapa kesimpulan sebagai berikut:

1. Berdasarkan uji t statistik yang dilakukan maka dapat disimpulkan bahwa variabel potongan harga berpengaruh positif dan signifikan terhadap keputusan pembelian impulsif yang ditunjukkan oleh nilai signifikansi sebesar $0,047<$ alpha 0,05 . Hasil uji regresi linear berganda menjelaskan bahwa setiap peningkatan potongan harga maka akan meningkatkan keputusan pembelian impulsif.

2. Berdasarkan uji t statistik yang dilakukan maka dapat disimpulkan bahwa promosi penjualan berpengaruh positif dan signifikan terhadap keputusan pembelian impulsif yang ditunjukkan oleh nilai signifikansi sebesar $0,000<$ alpha 0,05 . Hasil uji regresi 
linear berganda menjelaskan bahwa setiap peningkatan promosi penjualan maka akan meningkatkan keputusan pembelian impulsif.

3. Berdasarkan uji t statistik yang dilakukan maka dapat disimpulkan bahwa tampilan dalam toko berpengaruh positif dan signifikan terhadap keputusan pembelian impulsif yang ditunjukkan oleh nilai signifikansi sebesar $0,000<$ alpha 0,05 . Hasil uji regresi linear berganda menjelaskan bahwa setiap peningkatan tampilan dalam toko maka akan meningkatkan keputusan pembelian impulsif.

4. Berdasarkan uji f simultan yang dilakukan maka dapat disimpulkan bahwa potongan harga, promosi penjualan, dan tampilan dalam toko secara keseluruhan/bersama-sama berpengaruh signifikan terhadap keputusan pembelian impulsif.

5. Berdasarkan kesimpulan diharapkan perusahaan harus mampu memperhatikan potongan harga untuk mengantisipasi para pesaing, promosi penjualan untuk memikat konsumen agar tidak melakukan pembelian impulsif dan tampilan toko agar diperhatikan semenarik mungkin untuk memikat minat konsumen.

\section{E. DAFTAR PUSTAKA}

Amanah, D., \& Pelawi, S. P. (2015). Pengaruh Promosi Penjualan (Sales Promotion) dan Belanja Hedonis (Hedonic Shopping) Terhadap Impulsive Buying Produk Matahari Plaza Medan Fair. https://doi.org/10.17605/OSF.IO/SBDE3

Baskara, I. B. (2018). Pengaruh Potongan Harga (Discount) Terhadap Pembelian Tidak Terencana (Impulse Buying) (Studi Pada Pengunjung Matahari Department Store Johar Plaza Jember). Department of Management FEB UMM, 87-96.

Clara, M. (2017). Pengaruh Promosi Penjualan Terhadap Keputusan Pembelian Impulsif Ibu Rumah Tangga (Studi Kasus Department Store di Kota Bogor). Jurnal Ekonomi Dan Manajemen, 01(01).

Ghozali, I. (2017). Ekonometrika: Teori, Konsep dan Aplikasi Dengan IBM SPSS 24. Semarang: Badan Penerbit Universitas Diponegoro.

Kotler, P. dan K. L. K. (2018). Manajemen Pemasaran (edisi 13). jakarta: PT. Indeks.

Kristiawan, A. (2018). Pengaruh Potongan Harga , Bonus Kemasan , Tampilan dalam Toko terhadap Keputusan Pembelian Impulsif ., 6(Kotler 2010), 30-44.

Ma'arif, R. (2017). Strategi Pemasaran. Jakarta: PT. Indeks.

Machfoedz, M. dan M. M. (2015). Kewirausahaan (Metode, Manajemen, dan Implementasi). Yogyakarta: BPFE - Yogyakarta.

Melysa, D. (2018). Pengaruh Promosi Penjualan Terhadap Pembelian Impulsif Pada Pelanggan Swalayan Surya Tirtayasa, Bandar Lampung. Ekonomi Dan Bisnis, 01(01).

Mowen dan Minor. (2012). Perilaku Konsumen Jilid 1 (Edisi 5). Jakarta: Erlangga.

Sari, D. R. (2018). Pengaruh Price Discount, Bonus Pack, Dan In-Store Display Terhadap Keputusan Impulse Buying Pada Giant Ekstra Banjar. Jurnal Sains Manajemen Dan Kewirausahaan, 2(1).

Sugiyono. (2017). Statistik Untuk Penelitian. Bandung: Alfabeta Bandung.

Tjiptono, F. (2018). Strategi Pemasaran (4th ed.). Yogyakarta: CV. Andi.

Utami, C. W. (2016). Manajemen Ritel: Strategi dan Implementasi Ritel Modern. Jakarta: Salemba Empat.

Viona, L. S. (2018). Analisis pengaruh Promosi Penjualan Dan Store Atmosphere Terhadap Perilaku Pembelian Secara Impulsif Pada Toko Buku Gramedia (PT. Gramedia asri Media) di Manado. Fakultas Ekonomi Dan Bisnis, Jurusan Manajemen, 6(3), 1628-1637.

www.ceicdata.com, tanggal akses 10 Juni 2019

www.databoks.com, Tanggal Akses 10 Juni 2019 